\title{
A global synthesis of fire effects on pollinators
}

\section{Lucas M. Carbone ${ }^{1,2}$ ， Julia Tavella ${ }^{1}$ ， Juli G. Pausas ${ }^{3}$, Ramiro Aguilar ${ }^{1,4}$}

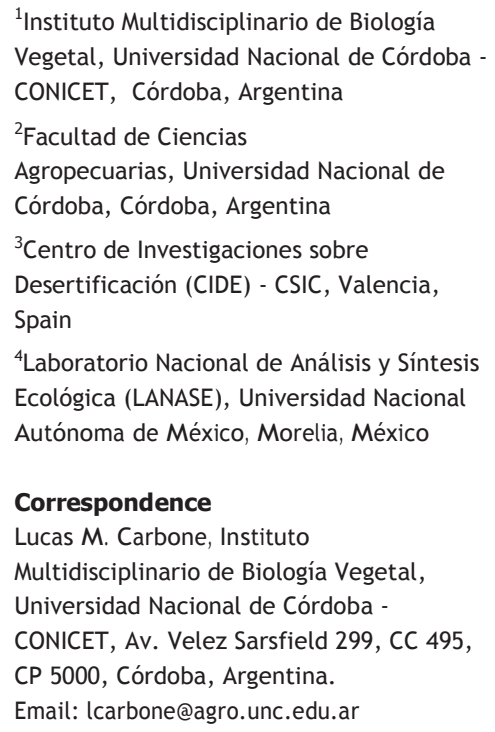

${ }^{4}$ Laboratorio Nacional de Análisis y Síntesis Ecológica (LANASE), Universidad Nacional Autónoma de México, Morelia, México

\section{Correspondence}

Lucas M. Carbone, Instituto

Multidisciplinario de Biología Vegetal,

Universidad Nacional de Córdoba -

CONICET, Av. Velez Sarsfield 299, CC 495,

CP 5000, Córdoba, Argentina.

Email: Icarbone@agro.unc.edu.ar

\begin{abstract}
Aim: Understanding fire effects on pollinators is critical in the context of fire regime changes and the global pollination crisis. Through a systematic and quantitative review of the literature, we provide the first global assessment of pollinator responses to fire. We hypothesize that pollinators increase after fire and during the early postfire succession stages; however, high fire frequency has the opposite effect, decreasing pollinators.
\end{abstract}

Location: Terrestrial ecosystems, excluding Antarctica.

Time period: Data collected from 1973 to 2017.

Major taxa studied: Insects (Coleoptera, Diptera, Hymenoptera and Lepidoptera) and a few bird species.

Methods: We first compiled available studies across the globe that assessed fire effects on pollinator communities. Then, by means of hierarchical meta-analyses, we evaluated how different fire regime parameters (fire frequency, postfire time and fire type) and habitat characteristics affect the abundance and richness of animals that act as pollinators. We also explored to what extent the responses vary among taxa groups and life history traits of pollinators (sociality system, nest location and feeding specialization), and among biomes.

Results: The overall effect size of fire on pollinator abundance and richness across all studies was positive. Fire effect was especially clear and significant in early postfire communities, after wildfires, and for Hymenoptera. Taxonomic resolution influenced fire effects, where only studies at the species/genus and family levels showed significant effects. The main exceptions were recurrent fires that showed a negative effect, and especially wildfire effects on Lepidoptera abundance that showed a significant negative response.

Main conclusions: Pollinators tend to be promoted after a wildfire event. However, short fire intervals may threat pollinators, and especially lepidopterans. Given the current fire regime changes at the global scale, it is imperative to monitor postfire pollinators across many ecosystems, as our results suggest that fire regime is critical in determining the dynamics of pollinator communities.

KE Y WO R D S:

fire regime, floral visitors, meta-analysis, plant-animal interaction, pollinator abundance, pollinator richness, postfire age, systematic review 


\section{INTRODUCTION}

Fire is an ecological and evolutionary factor that modulates the dynamics, diversity and structure of many terrestrial ecosystems across the Earth (Pausas \& Keeley, 2009). Fires not only modify plant and animal community compositions, but also the biotic interactions (García, Castellanos, \& Pausas, 2018; Pausas \& Parr, 2018), with consequences for ecosystem functioning and the services they provide. While the effect of wildfires on plant communities is well studied across many ecosystems around the world (Bradstock, Williams, \& Gill, 2012; Keeley, Bond, Bradstock, Pausas, \& Rundel, 2012; Pausas \& Ribeiro, 2017), their effect on biotic interactions is still poorly known. An especially relevant interaction is pollination, as most flowering plants (85\%), including most crops (75\%), rely on animal pollinators for sexual reproduction (Klein et al., 2007; Ollerton, Winfree, \& Tarrant, 2011). Anthropogenic changes of fire regimes are likely to affect the pollinators and thus the pollination process (Dirzo et al., 2014; Potts et al., 2010), with ecological and economic consequences in both natural and agricultural systems (Dirzo et al., 2014; McKechnie \& Sargent, 2013; Wilcock \& Neiland, 2002). However, there is still no global assessment of how pollinators respond to fire (Winfree, Aguilar, Vázquez, LeBuhn, \& Aizen, 2009). Understanding the effect of fire on pollinators is now becoming even more relevant with the current global fire regime changes (Chergui, Fahd, Santos, \& Pausas, 2018; Flannigan, Krawchuk, Groot, Wotton, \& Gowman, 2009; Keeley \& Syphard, 2016) and the global pollination crisis (Cariveau \& Winfree, 2015; Goulson, Nicholls, Botías, \& Rotheray, 2015; Potts et al., 2010).

Fire can affect biotic interactions by directly increasing mortality, or indirectly, by changing habitat structure, which affects visibility, resources and flowering pattern (García, Castellanos, \& Pausas, 2016, 2018; Knight \& Holt, 2005; Koltz et al., 2018; Peralta, Stevani, Chacoff, Dorado, \& Vázquez, 2017). Consequently, if the habitat conditions change (i.e., vegetation structure and composition) the pollinator community is also expected to change in response to variations in nesting and feeding resources. Because the availability of edaphic resources increases immediately after fire, there is also a postfire increase in flowering and hence in resources for pollinators. Early postfire successional species are typically short-lived that mature and flower earlier than woody long-lived species. Consequently, pollinator communities are likely to decrease with postfire age. However, high fire frequency maynegatively affect pollinator populations (directly or by modifying the habitat). In addition, short fire intervals may prevent many plants from reaching maturity and flowering ("immaturity risk"; Pausas \& Keeley, 2014; Zedler, 1995). Therefore, pollinators are likely to depend on the different components of fire regime like the frequency of fires (Lazarina et al. , 2017; Moretti, Obrist, \& Duelli, 2004), the time since fire (Brown, York, Christie, \& McCarthy, 2016; Potts et al., 2003; Swengel \& Swengel, 2007) and the spatial variability of these parameters (Brown, York, \& Christie, 2016; Ponisio et al., 2016). Understanding how fire regime factors affect pollinators is critical for planning conservation and management actions in the context of the Anthropocene (Dirzo et al. , 2014; Kellyet al., 2018).
At the community level, fire effects on pollinator diversity can vary depending upon the spatial scales at which they are measured. At the regional scale, fire creates patches of different postfire age, thereby increasing the between-patch heterogeneity as fire diversity increases (Ponisio et al., 2016; Wikars, 1997). At the local scale, where species interactions occur, fire events decrease competitive exclusion and thus increasing the diversity of species. However, too frequent fires with short return intervals eliminate plant and animal species without giving time for re-establishment (Connell, 1978; Kral, Limb, Harmon, \& Hovick, 2017). Therefore, the intermediate disturbance hypothesis (Huston, 1979) predicts that a moderate frequency or intensity of disturbances maintains high species diversity within a habitat. Thus, the loss of plant diversity and the vegetation changes induced by altered fire regime can trigger pollinator co-extinctions under high frequency of fires (Vieira, Cianciaruso, \& Almeida-Neto, 2013).

Pollinators may vary in their susceptibility to fire, depending on certain traits such as the degree of mobility, sociality, nesting behaviour and feeding habits (Kelly et al., 2018; Kral et al., 2017; Pausas, 2019). Many pollinators are good flyers and thus likely to recolonize or to forage in the burn area quickly as flowers are available (Carbone \& Aguilar, 2017; García et al., 2018; Peralta et al., 2017; Thom, Daniels, Kobziar, \& Colburn, 2015). In addition, groundnesting pollinators that survived the fire, as well as those with social organization may be benefited in burned environments due to lower competition for floral resources and lower predation levels (Koltz et al., 2018; Kral et al., 2017; Pausas \& Parr, 2018). Moreover, pollinators with generalist feeding habits tend to recolonize burned sites faster than pollinator specialists, as the latter need specific floral resources that may not be readily available in postfire communities (García et al., 2016; García et al., 2018; Geerts, Malherbe, \& Pauw, 2012; Kelly et al., 2018).

We therefore predict that a fire event promotes pollinator richness and abundance, as a result of the increased floral resources occurring immediately after the fire and the high pollinator mobility. Consequently, we expect a positive response of pollinators at the early postfire successional stages. However, we also expect that increased fire frequency will reduce pollinator diversity due to the drastic changes of habitat and resource depletion. Moreover, pollinator response to fire age may differ between vegetation physiognomies where grasslands may exhibit higher immediate postfire flowering and thus pollinator activity, whereas woody vegetation might take longer to restore high flowering levels. To test these predictions, we conducted a systematic literature review of the available studies across the globe that assessed fire effects on the community of floral visitors that are known to pollinate plants (pollinators hereafter). By means of hierarchical meta-analyses, we evaluate how different fire regime parameters (fire frequency, postfire time and fire type) and habitat characteristics (vegetation physiognomy) affect the abundance and richness of pollinators. We also explore to what extent the responses vary among taxa groups, life history traits of pollinators (sociality system, nest location and feeding specialization) and among biomes. 


\section{METHODS}

\subsection{Literature search and compilation of dataset}

We performed literature searches in three online databases (ISI Web of Knowledge, Fire Research Institute library (c) 2015 http: // www.fireresearchinstitute.org/, and Scopus), in English, Spanish and Portuguese, covering publications from January 1973 to October 2017, and using two independent keyword combinations. The first search involved the following string of keywords: ("fire* OR wildfire* OR *burn*) AND (pollinat* OR pollinator*), and was aimed at gathering all the studies assessing fire effects on the abundance and richness of pollinators, regardless of their taxonomic classification. A second search string of keywords was conducted to further search for studies assessing fire effects on certain taxonomic groups and common names of insects, birds, bats and non-flying mammals that are known to be pollinators, regardless of the interests of each primary study, to determine fire effects on plant-pollinator interactions: ("fire* OR wildfire* OR *burn*) AND (hymenoptera OR coleoptera OR lepidoptera OR anthomyiidae OR acroceridae OR calliphoridae OR muscidae OR sarcophagidae OR scathophagidae OR nemestrinidae OR apioceridae OR empididae OR syrphidae OR tachinidae OR bombyliidae OR trochilidae OR hummingbird* OR nectarinidae $O R$ promeropidae $O R$ meliphagidae $O R$ fringillidae $O R$ psittacidae OR sugarbird* OR sunbird* OR honeyeater* OR honey-

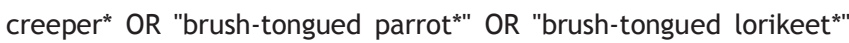
OR phyllostomidae OR pteropodidae OR bat* OR muridae OR lamuridae $O R$ callitrichidae $O R$ cebidae $O R$ didelphidae $O R$ dasyuridae OR burramyidae OR petauridae OR tarsipedidae) NOT (formicidae). Studies gathered from this second search were individually screened to identify whether the target taxon being studied was a pollinator or not. In all cases we only included studies that assessed fire effects on abundance or richness of animals that are frequent floral visitors and able to act as pollinators. We discarded all studies assessing fire effects on non-pollinator animals or on non-nectar/pollen feeding life stages (e.g., lepidopteran larvae). We excluded ants (Formicidae) from the literature search because ant pollination is not only very rare but it can also deplete plant reproduction by decreasing pollen viability, damaging floral sexual organs or competing with legitimate pollinators (e.g., Beattie, Turnbull, Knox, \& Williams, 1984). We also excluded parasitic and parasitoid species because the response of these high-trophic-level organisms may depend on factors related to the fire response of their host species, which goes beyond the objectives of this review. This initial search yielded 2,820 articles (see Supporting Information Figure S1) and included studies reported by the previous meta-analysis of Winfree et al. (2009).

For a study to be included in our review, it had to report fire effects on the abundance or richness of a pollinator taxon and had to provide numerical parameters to compute the effect sizes (see below), the common metric to conduct a meta-analysis. The final list of the studies included in the meta-analysis is found in the Appendix: Data sources. In those studies, pollinator abundance was mainly estimated as the number of individuals within a sampling unit (e.g., transect, parcel, trap, etc.) or the visitation rate to flowers at the species level. However, in some cases, abundance was estimated at the genus, family or order taxonomic levels. Species richness was mostly measured as the number of species of different taxonomic levels (family or order), and only a few studies used other diversity indexes.

For each study, we defined the following variables related to the characteristics of the fire considered, and the type and conditions of the study: Fire frequency (classified as "once burned vs. unburned", or "repeated burned vs. unburned"); Fire age (age at which the postfire assessment was performed; "early": 3 years or less; "late”: otherwise); Fire Type (prescribed vs. wildfire); Pollinator taxa (birds, Coleoptera, Diptera, Hymenoptera or Lepidoptera); Biome (following Olson et al., 2001); vegetation physiognomy (forest, grassland or shrubland); Pollinator feeding specialization (generalist vs. specialist pollinator); Sociality (social/semi-social vs. solitary; for bees); and Nest location (aboveground vs. belowground).

\subsection{Meta-analysis}

We used Hedges' $d$, the standardized mean difference, as the effect size measure across all studies, which has the advantage of being unbiased by small sample size (Gurevitch, Curtis, \& Jones, 2001). We calculated Hedges' $d$ in three ways: (a) For most of the studies, Hedges' $d$ was calculated straightforwardly from the mean values, sample sizes and standard deviations of abundance and/or species richness in each of the two contrasting fire conditions: the control (unburned, long-time since last fire or mature forests) and the treatment (burned, single or repeated). (b) In studies providing correlational data (e.g., postfire time or fire frequency gradients), we calculated the Pearson's correlation coefficient $r$ and the sample size (Rosenberg, Rothstein, \& Gurevitch, 2013). (c) For studies presenting pollinator presence/absence data in burned and unburned conditions, we used two $\times$ two contingency tables to calculate the odds ratio, which expresses the probability of occurrence of a species in burned and unburned conditions in relation to its total occurrence (Rosenberg et al., 2013). Correlation coefficients and the log of the odds ratio were mathematically transformed into Hedges' $d$ following Borenstein, Hedges, Higgins, and Rothstein (2009). Negative values of $d$ imply a decrease in the mean value of the abundance or richness of pollinators in burned conditions, whereas a positive $d$ value corresponds to an increase as compared to the unburned conditions.

We conducted hierarchical mixed effects meta-analyses for each response variable (abundance and richness). That is, inversevariance-weighted models that included fixed (see moderators below) and random effects to estimate the differences across studies, assuming they do not share a common mean effect but that there is random variation among them, in addition to withinstudy sampling variation (Borenstein et al., 2009). The models also took into account the hierarchical dependence in our data due to cases where multiple data points (i.e., effect sizes) were obtained from the same paper, by including a publication-level random effect as a nesting factor (Stevens \& Taylor, 2009; see models in Supporting Information Table S1). 
The heterogeneity of effect sizes was assessed with $Q$ statistics, which are weighted sums of squares tested against a $\chi^{2}$ distribution (Hedges \& Olkin, 1985). Specifically, we examined the $p$ values of $Q_{\text {between }}\left(Q_{b}\right)$ statistics that describe the variation in effect sizes that can be attributed to differences among categories of each predictor variable. A significant value of $Q_{b}$ indicates that categories being compared have different effects of fire. Specifically, we tested the following predictor variables: Fire frequency, Fire age, Fire Type, Biome, Vegetation physiognomy, Pollinator taxa, Feeding specialization, Sociality and Nest location (see Supporting Information Table S2). We also included the overall fire effect, which considers all studies independent of their experimental details. We conducted a sensitivity analysis to explore whether the taxonomic level at which the effects were measured affected the overall effect size of pollinator response to fire. This analysis required the recalculation of the overall effect after eliminating one taxonomic level at a time. An effect of fire was considered significant if the $95 \%$ confidence intervals ( $\mathrm{Cls}$ ) of the effect size $(d)$ did not overlap zero (Rosenberg et al. , 2013). We performed all the analyses in R using the "metaphor" package with the restricted maximum likelihood "REML" method (R Core Team, 2018, version 3.3.0; Viechtbauer, 2010). Datasets used in the meta-analyses are found in Supporting Information Tables S4 and S5.

\subsection{Publication bias}

An intrinsic problem in any systematic quantitative review is the possibility of publication bias, that is, studies showing significant results have a higher probability of being published. We explored the potential of publication bias in our dataset by two different methods. (a) We assessed the Kendall's rank correlations of effect size and standard error across the studies (Begg, 1994); significant $p$ values indicate potential publication bias, whereby studies with small sample size (large standard errors) are only published if they show large effect sizes. (b) We performed the "trim and fill" method, which is used as a sensitivity analysis that recalculates the estimated mean effect size; this provides an estimate of how the overall effect size would change if we were able to incorporate all missing studies (Jennions \& Møller, 2002).

\section{RESULTS}

We identified 65 studies across 21 countries of the 5 continents (Supporting Information Figure S2) that meet our criteria for inclusion in the review. Among these, 59 studies reported abundance data and 36 richness data, which yielded 293 data points (effect size values) for pollinator abundance and 99 data points for species richness (Supporting Information Figure S1). As expected, most of pollinators studied were insects, a few were birds (Apodiformes and Passeriformes; Figure 1) and only one study reported data of a marsupial pollinator. Among the studied insect pollinators, more than $50 \%$ were Hymenoptera, and more than $20 \%$ were Lepidoptera species (Figure 1). Very few studies reported data for Diptera and Coleoptera species. On the other hand, most studies analysed the pollinator response to fire by comparing once burned versus unburned conditions (61 and $86 \%$ of the effect sizes for richness and abundance, respectively), and only a few considered fire frequency (repeated burned, Figure 1). Fire effects were measured in a wide range of postfire time periods: from immediately after the burn up to 25 years after the fire. In relation to fire type, two-thirds of the richness effect sizes were obtained from prescribed fires while almost half of the abundance effect sizes come from wildfires. Among biomes, extratropical environments were overrepresented, especially from Mediterranean and temperate forest, followed by boreal and subtropical open habitats (Figure 1, Supporting Information Figure S2).

The overall weighted-mean effect size of fire on pollinator abundance and richness across all studies was positive (although non-significantly different from zero for richness; i.e., confidence intervals slightly overlapping 0; Figure 2, Supporting Information Table S2a). The total heterogeneity of effect sizes was large and statistically significant for both abundance and richness (Supporting Information Table S3a), suggesting that fire effects may differ among the different factors considered. Fire frequency and time since fire largely explained the heterogeneity of abundance and richness of pollinators (Supporting Information Table S3a). The mean effect size was positive for the once burned/unburned comparison, but negative for the reburned/unburned comparison (Figure 2). In the latter case, the variability is large and Cls overlap zero. Pollinator abundance and richness increased in early postfire ( $\leq 3$ years) but had no effect in late postfire (Figure 2, Supporting Information Table S2a). Pollinator response to postfire age was similar among vegetation physiognomies, and none of them showed significant effects of fire on richness and abundance, with the exception of early-postfire grasslands, which showed a significant increase in abundance of pollinators (Supporting Information Figure S3). In relation to the fire type, the mean effect size was positive only for wildfires for both richness and abundance (Figure 2). The sensitivity analysis indicated that studies assessing pollinators at finer taxonomic resolution (family, genus/ species) showed a significant positive overall effect on pollinator abundance (Supporting Information Figure S4). These results imply that assessing fire effects at higher taxonomic levels such as orders can yield low precision estimates for abundance but not for richness. Within the same order there may be species responding to fire in contrasting directions, thereby resulting in null effect sizes at the order level. The sensitivity analysis on richness showed no changes across the taxonomic levels.

The response of the different pollinator taxa to fire was relatively homogeneous (i.e., $Q_{b}$ was not significant; Supporting Information Table S3a). The effect size tended to be negative for birds (abundance) and Lepidoptera (richness) and significantly positive for the abundance of Hymenoptera. For Diptera and Coleoptera, these positive trends were non-significant due to the large variability of low replicates for each category (Figure 3a). When looking at the effect of wildfires only (i.e., excluding prescribed fires), the negative effect on Lepidoptera and the positive effect on Hymenoptera became significant (Figure 3b, Supporting Information Tables S2b, S3b). 


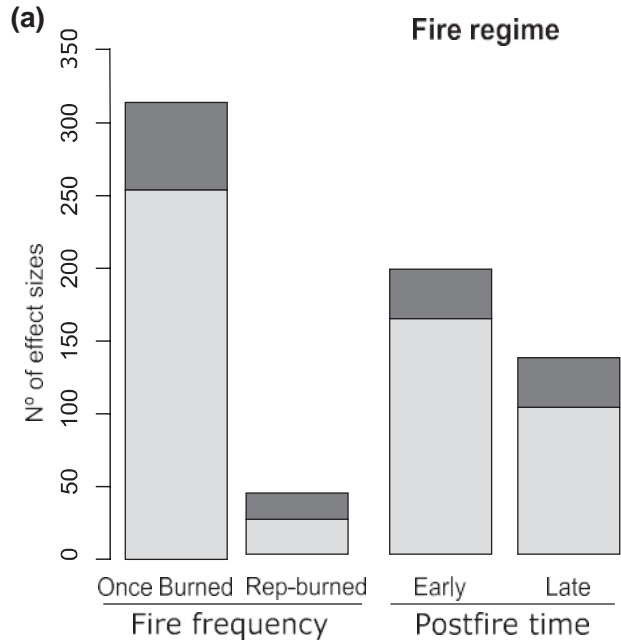

(b)

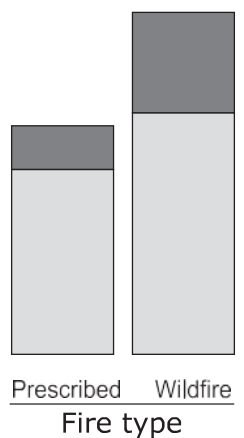

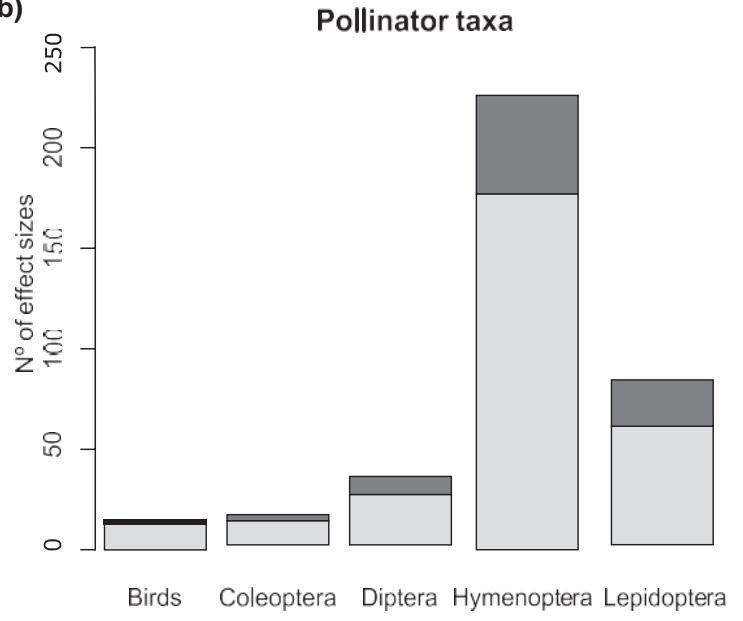

(c)

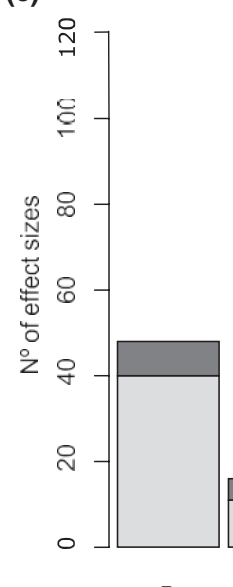

Biome

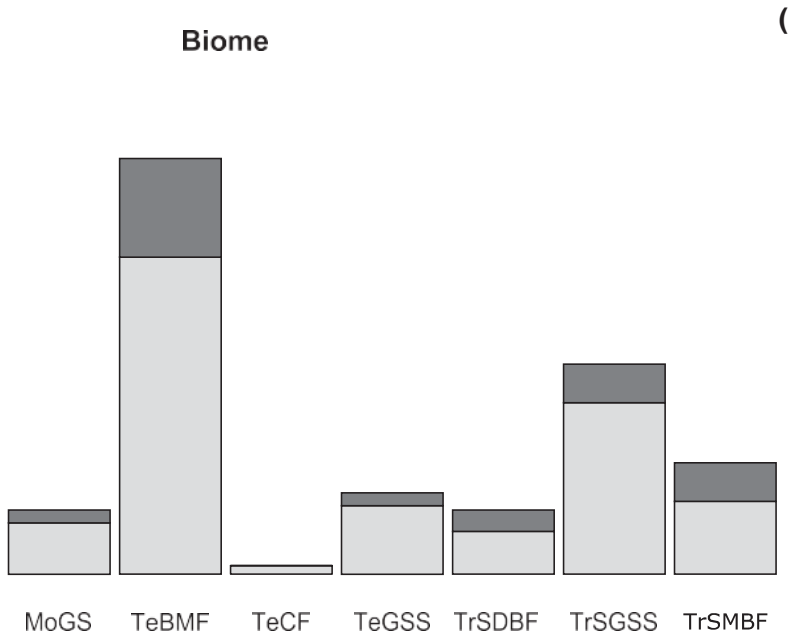

(d)

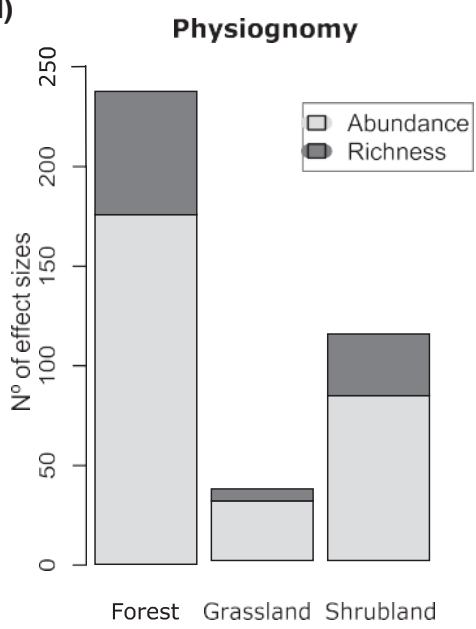

F I G U R E 1 Number of effect sizes within each moderator variable for abundance (dark grey) and richness (light grey) datasets: (a) fire regime factors: fire frequency (once burned-unburned, repeated burned-unburned), postfire time (early, late) and fire type (prescribed, wildfire); (b) pollinator taxa (birds, Coleoptera, Diptera, Hymenoptera, Lepidoptera); (c) biome: B = boreal; DXS = deserts and xeric shrublands; MeFWS = Mediterranean forest, woodlands and scrubland; MoGS = montane grasslands and shrublands; TeBMF = temperate broadleaf and mixed forests; TeCF = temperate coniferous forest; TeGSS = temperate grasslands, savannas and shrublands; TrSDBF = tropical and subtropical dry broadleaf forests; TrSGSS = tropical and subtropical grasslands, savannas and shrublands; TrSMBF = tropical and subtropical moist broadleaf forests; and (d) vegetation physiognomy: forest, grassland and shrubland

Looking at the abundance of Hymenoptera, the group with most information $(n=174)$, there was no differential response to fire between different degrees of feeding specialization (specialist/generalists), or between nesting habitats (below/above ground), or between sociality systems (solitary/social; Supporting Information Table S2a). In all cases, mean effect size was positive, and significant for belowground nesting and social behaviour (Supporting Information Table S2a). Finally, pollinator species from different biomes and physiognomies (forest, shrubland and grassland) responded fairly similarly (Supporting Information Table S2a), with a positive tendency in temperate forest and grasslands (Supporting Information Figure S5).

Rank correlation tests for funnel plot asymmetry (Supporting Information Figure S6) indicate that our datasets are not subject to publication bias (Kendall's $\tau_{\text {abundance }}=-0.052, p=0.187$; Kendall's $\tau_{\text {richness }}=0.059, p=0.392$ ); that is, there is no relationship between effect size magnitude and sample size. Accordingly, the recalculated unbiased overall effect size after incorporating all potentially non-significant missing studies was $-0.05(p=0.273, \mathrm{Cl}=-0.142$ to $0.040)$ for pollinator abundance and $0.20(p=0.033, \mathrm{Cl}=0.017-$ 0.385 ) for richness, which does not differ from the outputs of our original database.

\section{DISCUSSION}

Our results show that overall, and for most fire factors considered, the effect of fire is positive (Figure 2), thereby increasing the abundance and richness of floral visitors able to pollinate (pollinators). Fire effect was especially clear and significant in early postfire communities, afterwildfires, and for Hymenoptera (the largest group of pollinators). 


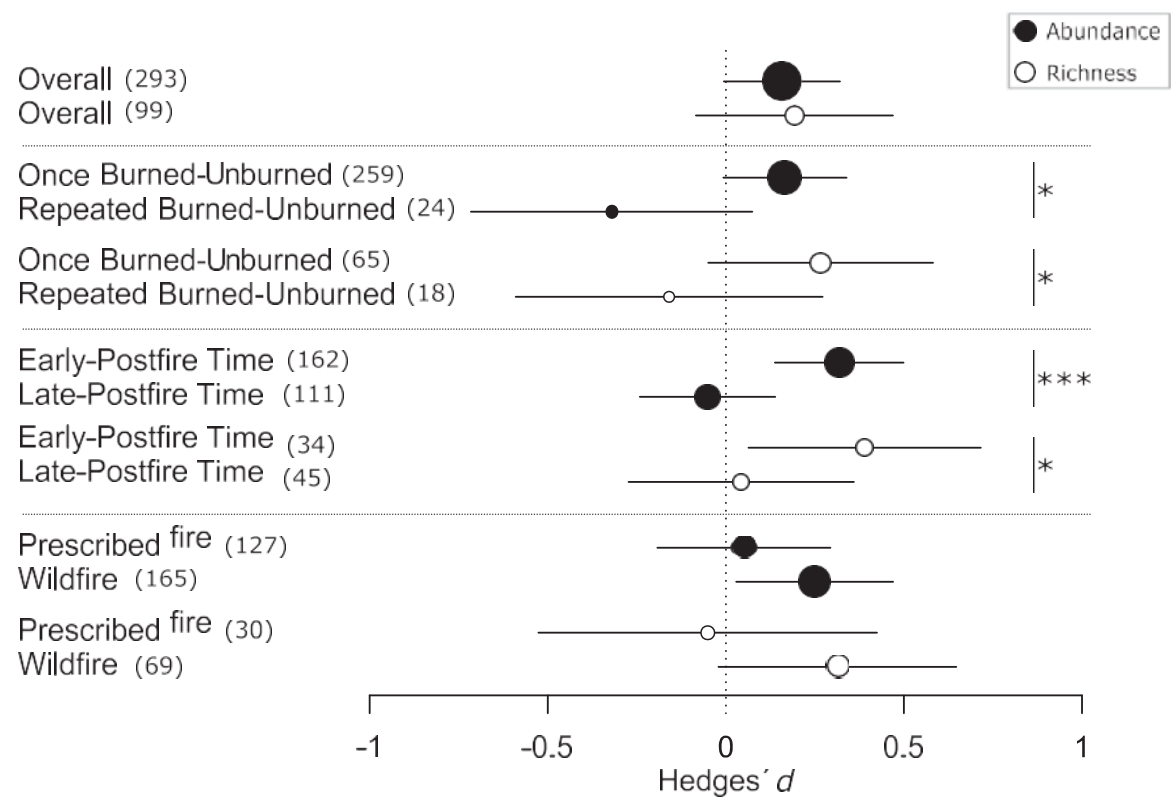

F I G U R E 2 Weighted-mean effect sizes and 95\% bias-corrected confidence intervals of fire on abundance (closed circles) and richness (open circles) of pollinators. The effect sizes of overall abundance and richness, fire frequency (once burned-unburned, repeated burnedunburned), postfire time (early, late), and fire type (prescribed fire, wildfire) are shown from the top to bottom. Parameters with confidence intervals that do not overlap the vertical dotted line (Hedge's $d=0$ ) are considered to have a significant positive or negative effect. Sample sizes for each category are shown in parentheses. The size of each symbol is proportional to its weight or contribution to the overall mean calculation. Asterisk denotes a significant difference $\left(Q_{\text {between }}\right)$ among categories $\left({ }^{* * *} p<0.0001 .{ }^{*} p<0.05\right)$
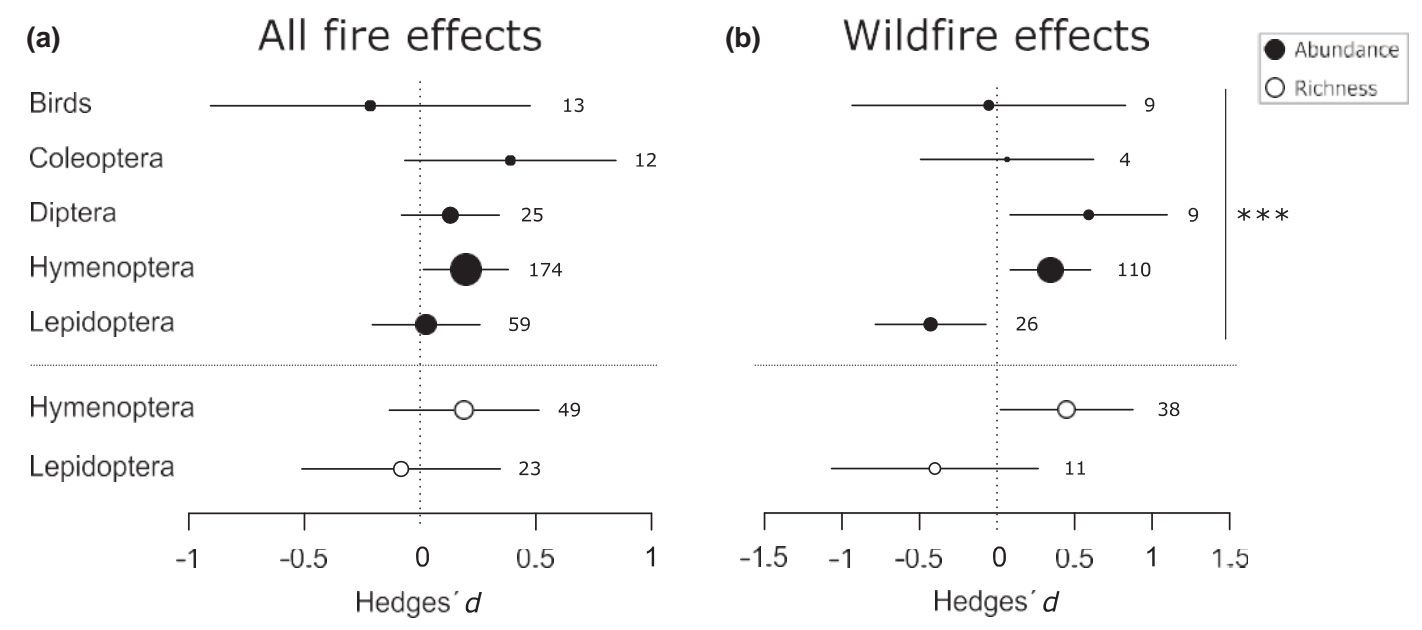

FIGURE 3 Weighted-mean effect sizes and 95\% bias-corrected confidence intervals of all fire effects (a; i.e., considering prescribed and wildfires), and considering wildfire only (b), on abundance (closed circles) and richness (open circles) of pollinator taxa: birds, Coleoptera, Diptera, Hymenoptera and Lepidoptera. Parameters with confidence intervals that do not overlap the vertical dotted line (Hedge's $d=0$ ) are considered to have a significant positive or negative effect. Sample sizes for each category are shown on the right of each effect. The size of each symbol is proportional to its weight or contribution to the overall mean calculation. Asterisks denote a significant difference $\left(Q_{\text {between }}\right)$ among categories $\left({ }^{* * *} p<0.0001\right)$

These results suggest that the pollinator community is not only resilient to wildfire, but it has a tendency to increase in postfire conditions. The main exception was recurrent fires that showed a negative (nonsignificant) tendency, and especially wildfire effects on Lepidoptera abundance which showed a significant negative response. Our results concur with the overall positive response to fire previously found for different animal guilds, including arthropods (Kral et al., 2017; Pressler,
Moore, \& Cotrufo, 2019) and some vertebrates (Buchalski, Fontaine, Heady, Hayes, \& Frick, 2013; Fontaine \& Kennedy, 2012; Kalies, Chambers, \& Covington, 2010). The fact that pollinators are mostly insect flyers, and thus they can quickly colonize burned areas, may explain their resilience to fire (Kral et al., 2017; Swengel, 2001). In addition, the typical increase in flowers after fire (due to more resources and less competition) may contribute to the positive tendency. 
The different fire regime characteristics are key for determining species fire tolerance and diversity (Keeley, Pausas, Rundel, Bond, \& Bradstock, 2011; Pausas, 2019). For instance, polli- nators responded positively to a single fire event in relation to unburned habitats, and more clearly under wildfires. In contrast, repeated fires showed an overall negative (although non-signifi- cant) tendency. That is, sites that exhibited several consecutives fires showed a trend of lower pollinator abundance and richness in comparison to unburned sites (Figure 2). The fire interval in these studies ranged from 10 to 12 years ( $S D=5-7$ years be- tween fires), and they largely corresponded to wildfires (69\%) in extratropical biomes. That is, under non-tropical environments these short fire intervals tend to be detrimental for pollinators, as for other organisms (Kowaljow et al., 2018; Kral et al., 2017). However, we cannot disentangle whether this reduction of pol- linators is due to reduced flowering (i.e., immaturity risk under short fire intervals) or to a direct negative effect on pollinators, and thus a disruption of the pollination interaction (Kowaljow et al., 2018; Vieira et al., 2013).

The positive effect of fire on pollinators can also be seen when we look at the time since fire, as only early postfire stud- ies showed a significant positive fire effect on both abundance and richness (Figure 2). That is, pollinators benefit from recently burned environments. Late postfire communities (3 or more years after fire) showed no effect of fire on pollinators, suggesting that pollinator increase after fire is transient. The increase of diversity and abundance of nectar providing plants immediately after a fire (LoPresti et al., 2018; Mola \& Williams, 2018; Potts et al., 2003; Van Nuland et al., 2013), the higher nectar production (Ne'eman \& Dafni, 1999) and particularly the high nectar concentration of plant species that germinate profusely after fires (obligate seed- ers, Carpenter \& Recher, 1979; Ne'eman, Dafni, \& Potts, 2000) support the preference for early postfire vegetation. In addition, pollinator response to postfire age was little affected by vegeta- tion physiognomy (grassland, shrubland, forest), with only early postfire grasslands showing higher pollinator abundance. These results suggest that increasing flowering postfire is quite gen- eral across vegetation types (Lamont \& Downes, 2011). The high number of herbaceous species in fire-prone environments with floral phenology synchronized by fire (Lamont \& Downes, 2011; Pilon, Hoffmann, Abreu, \& Durigan, 2018) can be quite attractive to pollinators, explaining the higher pollinator visitation to floral-resource-rich communities of recently burned sites (Mola \& Williams, 2018; Swengel, 2001).

While wildfires showed a clear positive effect on pollinators, prescribed fires had no effect on abundance or richness (Figure 2). The fact that these burns tend to be lighter, smaller and patchier may cause less changes in the vegetation (composition, structure), and in the associated fauna. In addition, prescribed fires may be often performed in already open communities, or in understorey of woodlands, and thus the changes in structure are low. In contrast, unmanaged wildfires likely cause more drastic changes in vegetation structure and composition (Carbone, Aguirre-Acosta, Tavella,
\& Aguilar, 2017; Kowaljow et al., 2018; Pellegrini et al., 2018) allowing a more significant change (increase) in floral resources for pollinators. The importance of changes in community structure is also evident given that the case studies with the highest positive effect sizes were all temperate forests subject to crown fires (e.g., Bogusch, Blažej, Trýzna, \& Heneberg, 2015; Moretti et al., 2004; Taylor \& Catling, 2011). Unlike other insect functional guilds, such as soil arthropods that are not differently affected by fire type (Pressler et al., 2019), insect pollinators appear to depend to a large extent on strong aboveground changes. Therefore, generalizations should be applicable with caution to conditions only within comparable animal guilds and disturbance type (Kral et al., 2017).

Pollinating birds tend to be negatively affected by fire, although with high variability (Fraser, 1989; Geerts et al., 2012; but see Fontaine \& Kennedy, 2012; Kalies et al., 2010), while the abundance of insects, especially Hymenoptera, exhibits on average a positive trend in burned scenarios (Figure 3a). When only looking at the wildfires, the positive response of Hymenoptera and the negative trend of Lepidoptera become significant (Figure 3b). Pollinators that are resilient to fire show life history traits or response strategies to survive fires, or to quickly recolonize or forage in the postfire area (Pausas, 2019; Pausas \& Parr, 2018; Williams et al., 2010). Given that most of the studies do not identify whether pollinators are really nesting in burned areas, it is not possible to discern individuals foraging within but living outside the burned areas from a full recolonization. In addition, removal of predators, parasites and competitors for the same feeding resources may confer a fitness benefit by stimulating pollinator reproduction in burned places, as happens with some pyrophilous insects (New, 2014; Pausas, Belliure, Mínguez, \& Montagut, 2018). For instance, within Hymenoptera pollinators, we expected that traits such as social organization, underground nesting and generalist pollinators should present advantages in burned sites. This is because social hymenopterans have bigger colonies, and groundnesting species are better protected from the heat and thus likely to be favoured (Cane \& Neff, 2011; Mola \& Williams, 2018; Williams et al., 2010). Our results partially support these predictions because fire increased the abundance of social and below ground-nesting bees (Supporting Information Table S2a). The response to fire of bees with different nesting behaviour can depend on the postfire age, because the nesting resource (bare soil or vegetation) changes with postfire succession (Lazarina et al., 2019; Williams et al., 2010).

Lepidoptera abundance tends to decrease under wildfire regimes. Habitat specialists and oligolectic butterflies are often underrepresented after wildfires (Cleary et al., 2004; Swengel, 1998,

2001; Swengel \& Swengel, 2013). However, we tested adult butterflies' habitat preference (generalist versus specialist) and feeding behaviour at the larval life stage (polylectic versus oligolectic) as moderators and failed to find significant differences (not shown). Therefore, the negative response of Lepidoptera to wildfires is likely due to the higher larvae susceptibility to direct fire effects than Hymenoptera, which typically nest in more protected microsites (e.g., belowground or woody holes). In addition, it is likely that increased light in burned habitats and consequent changes in leaf 
tissues, which lepidopteran larvae depend on, could be responsible for the lower butterfly abundance after wildfires (Cariveau \& Winfree, 2015; Kral et al., 2017; Swengel, 2001).

While our results show clear response patterns, it is important to underline that the current available research about the role of fire on pollinators is still limited for some ecosystems, like savannas and other tropical ecosystems. Thus, our review also evidences gaps in the current knowledge (Figure 1). Our synthesis was not able to include the effect of important spatial factors like fire size (García et al., 2016, 2018) and the spatial heterogeneity of fire regime parameters (Brown \& York, 2017; Lazarina et al., 2019; Ponisio et al., 2016), which are highly related to the mobility of the animals and their landscape scale persistence (Pausas, 2019). There are not enough studies that analyse the spatial component of the fire regime to be able to perform a global meta-analysis. Another factor that requires further work at the local and regional scales is to study the changes in the pollinator composition (species turnover) in relation to fire (García et al., 2018; Moretti, De Bello, Roberts, \& Potts, 2009) and the ecological consequences for the plant populations of having a larger and richer pollinator community right after fires (LoPresti et al., 2018).

In conclusion, we present the first global synthesis of empirical evidence across multiple pollinator functional groups and show that pollinators are not only resilient to fire, but they also tend to be promoted during the first postfire years. We also found evidence that short fire intervals in non-tropical ecosystems may be a threat to pollinators, and especially lepidopterans. This is critical because it emphasizes the importance of fire regime (and not fire per se; Keeley et al., 2011) in determining the winners and losers in fire-prone ecosystems. Given the ongoing global fire regime changes, it is imperative to monitor postfire pollination across many ecosystems, as our results suggest that fire regime is critical in determining the dynamics of pollinator communities, and thus of the pollination service.

\section{ACKNOWLEDGMENTS}

We thank all authors that provided data for this meta-analysis. We appreciate the valuable comments and suggestions made by two anonymous referees and the editor that helped to considerably improve the manuscript. This research was financed by Secretaría de Ciencia y Tecnología, Universidad Nacional de Córdoba (33820180100138CB), Consejo Nacional de Investigaciones Científicas y Técnicas (CONICET-PIP 0371), Fondo para la Investigación Científica y Tecnológica (FONCYT-PICT 2016-0764), and the Spanish Government (FILAS project, CGL2015-64086-P). LMC and RA are a post-doc fellow and researcher of CONICET, respectively. JT is a researcher of Instituto Multidisciplinario de Biología Vegetal (IMBIV, UNC-CONICET) and JGP is a researcher of Centro de Investigaciones sobre Desertificación, Consejo Superior de Invetigaciones Científicas (CIDE-CSIC).

\section{AUTHOR CONTRIBUTION}

LMC and RA conceived the original idea, performed the literature search and the statistical analyses. LMC, JT and RA obtained the parameters to compute the effect sizes and the predictor variables from the studies. LMC administered the project, the data curation and wrote the first draft of the manuscript. JGP contributed to the conceptualization, formulation and evolution of this study. All authors contributed to the writing, review and editing of the final manuscript.

\section{DATA ACCESSIBILIT Y}

The authors confirm that all data underlying the findings are fully available without restriction. The datasets used to perform this review are available in Supporting Information Tables S4 and S5.

\section{REFERENCES}

Beattie, A. J., Turnbull, C., Knox, R. B., \& Williams, E. G. (1984). Ant inhibition of pollen function: A possible reason why ant pollina- tion is rare. American Journal of Botany, 71, 421-426. https://doi. org/10.1002/j.1537-2197.1984.tb12527.x

Begg, C. B. (1994). Publication bias. In H. Cooper \& L. V. Hedges (Eds.), The handbook of research synthesis (pp. 399-409). New York, NY: Russell Sage Foundation.

Bogusch, P., Blažej, L., Trýzna, M., \& Heneberg, P. (2015). Forgotten role of fires in Central European forests: Critical importance of early post-fire successional stages for bees and wasps (Hymenoptera: Aculeata). European Journal of Forest Research, 134(1), 153-166. https ://doi.org/10.1007/s10342-014-0840-4

Borenstein, M., Hedges, L. V., Higgins, J. P. T., \& Rothstein, H. R. (2009). Introduction to meta-analysis. West Sussex, UK: John Wiley \& Sons.

Bradstock, R. A., Williams, J. E., \& Gill, A. M. (2012). Flammable Australia. Fire regimes, biodiversity and ecosystems in a changing world. Victoria, Australia: CSIRO Publishing.

Brown, J., \& York, A. (2017). Fly and wasp diversity responds to elements of both the visible and invisible fire mosaic. International Journal of Wildland Fire, 26(5), 434-443. https://doi.org/10.1071/WF16189

Brown, J., York, A., \& Christie, F. (2016). Fire effects on pollination in a sexually deceptive orchid. International Journal of Wildland Fire, 25(8), 888-895. https://doi.org/10.1071/WF15172

Brown, J., York, A., Christie, F., \& McCarthy, M. (2016). Effects of fire on pollinators and pollination. Journal of Applied Ecology, 54(1), 313-322. https://doi.org/10.1111/1365-2664.12670

Buchalski, M. R., Fontaine, J. B., Heady, P. A., III, Hayes, J. P., \& Frick, W. F. (2013). Bat response to differing fire severity in mixed-conifer forest California, USA. PLOS ONE, 8(3), e57884. https://doi.org/10.1371/ journal.pone.0057884

Cane, J. H. , \& Neff, J. L. (2011). Predicted fates of ground-nesting bees in soil heated by wildfire: Thermal tolerances of life stages and a survey of nesting depths. Biological Conservation, 144(11), 2631-2636. https:// doi.org/10.1016/j.biocon.2011.07.019 
Carbone, L. M., \& Aguilar, R. (2017). Fire frequency effects on soil and pollinators: What shapes sexual plant reproduction? Plant Ecology, 218, 1283-1297. https://doi.org/10.1007/s11258-017-0768-0

Carbone, L. M., Aguirre-Acosta, N., Tavella, J., \& Aguilar, R. (2017). Cambios florísticos inducidos por la frecuencia de fuego en el Chaco Serrano. Boletín de la Sociedad Argentina de Botánica, 52(4), 753-778. https://doi.org/10.31055/1851.2372.v52.n4.18861

Cariveau, D. P., \& Winfree, R. (2015). Causes of variation in wild bee responses to anthropogenic drivers. Current Opinion in Insect Science, 10, 104-109. https://doi.org/10.1016/j.cois.2015.05.004

Carpenter, F. L., \& Recher, H. F. (1979). Pollination, reproduction, and fire. The American Naturalist, 113(6), 871-879. https://doi. org $/ 10.1086 / 283442$

Chergui, B. , Fahd, S. , Santos, X., \& Pausas, J. G. (2018). Socioeconomic factors drivefire-regimevariability in theMediterranean Basin. Ecosystems, 21(4), 619-628. https://doi.org/10.1007/s10021-017-0172-6

Cleary, D. F., Mooers, A. Ø., Eichhorn, K. A., Van Tol, J., De Jong, R., \& Menken, S. B. (2004). Diversity and community composition of butterflies and odonates in an ENSO-induced fire affected habitat mosaic: A case study from East Kalimantan, Indonesia. Oikos, 105(2), 426-448. https://doi.org/10.1111/j.0030-1299.2004.12219.x

Connell, J. H. (1978). Diversity in tropical rain forests and coral reefs. Science, 199, 1302-1310. https://doi.org/10.1126/science.199.4335. 1302

Dirzo, R., Young, H. S., Galetti, M., Ceballos, G., Isaac, N. J., \& Collen, B. (2014). Defaunation in the Anthropocene. Science, 345(6195), 401-406.

Flannigan, M. D., Krawchuk, M. A., de Groot, W. J., Wotton, B. M., \& Gowman, L. M. (2009). Implications of changing climate for global wildland fire. International Journal of Wildland Fire, 18(5), 483-507. https://doi.org/10.1071/WF08187

Fontaine, J. B., \& Kennedy, P. L. (2012). Meta-analysis of avian and smallmammal response to fire severity and fire surrogate treatments in US fire-prone forests. Ecological Applications, 22(5), 1547-1561. https:// doi.org/10.1890/12-0009.1

Fraser, M. W. (1989). Short-term responses of birds to fire in old mountain fynbos. Ostrich: Journal of African Ornithology, 60(4), 172-182. https://doi.org/10.1080/00306525.1989.9633753

García, Y., Castellanos, M. C., \& Pausas, J. G. (2016). Fires can benefit plants by disrupting antagonistic interactions. Oecologia, 182, 11651173. https://doi.org/10.1007/s00442-016-3733-z

García, Y., Castellanos, M. C., \& Pausas, J. G. (2018). Differential pollinator response underlies plant reproductive resilience after fires. Annals of Botany, 122, 961-971. https://doi.org/10.1093/aob/mcy122

Geerts, S., Malherbe, S. D., \& Pauw, A. (2012). Reduced flower visitation by nectar-feeding birds in response to fire in Cape fynbos vegetation, South Africa. Journal of Ornithology, 153(2), 297-301. https:// doi.org/10.1007/s10336-011-0743-9

Goulson, D., Nicholls, E., Botías, C., \& Rotheray, E. L. (2015). Bee declines driven by combined stress from parasites, pesticides, and lack of flowers. Science, 347(6229), 1255957. https://doi.org/10.1126/science. 1255957

Gurevitch, J., Curtis, P. S., \& Jones, M. H. (2001). Meta-analysis in ecology. Advances in Ecological Research, 32, 205-207.

Hedges, L. V., \& Olkin, I. (1985). Statistical methods for meta-analysis. New York, NY: Academic Press.

Huston, M. (1979). A general hypothesis of species diversity. The American Naturalist, 113(1), 81-101. https://doi.org/10.1086/283366

Jennions, M. D., \& Møller, A. P. (2002). Publication bias in ecology and evolution: An empirical assessment using the 'trim and fill' method. Biological Reviews, 77(2), 211-222. https://doi.org/10.1017/S1464793101005875 Kalies, E. L., Chambers, C. L., \& Covington, W. W. (2010). Wildlife re- sponses to thinning and burning treatments in southwestern conifer forests: A meta-analysis. Forest Ecology and Management, 259(3), 333-342. https://doi.org/10.1016/j.foreco.2009.10.024
Keeley, J. E., Bond, W. J., Bradstock, R. A., Pausas, J. G., \& Rundel, P. W. (2012). Fire in Mediterranean ecosystems: Ecology, evolution and management. UK: Cambridge University Press.

Keeley, J. E., Pausas, J. G., Rundel, P. W., Bond, W. J., \& Bradstock, R. A. (2011). Fire as an evolutionary pressure shaping plant traits. Trends in Plant Science, 16(8), 406-411. https://doi.org/10.1016/j.tplan ts.2011.04.002

Keeley, J. E., \& Syphard, A. D. (2016). Climate change and future fire regimes: Examples from California. Geosciences, 6(3), 37. https://doi. org/10.3390/geosciences6030037

Kelly, L., Brotons, L., Giljohann, K., McCarthy, M., Pausas, J., \& Smith, A. (2018). Bridging the divide: Integrating animal and plant paradigms to secure the future of biodiversity in fire-prone ecosystems. Fire, 1(2), 29. https://doi.org/10.3390/fire1020029

Klein, A. M., Vaissiere, B. E., Cane, J. H., Steffan-Dewenter, I., Cunningham, S. A., Kremen, C., \& Tscharntke, T. (2007). Importance of pollinators in changing landscapes for world crops. Proceedings of the Royal Society B: Biological Sciences, 274(1608), 303-313.

Knight, T. M., \& Holt, R. D. (2005). Fire generates spatial gradients in herbivory: An example from a Florida sandhill ecosystem. Ecology, 86, 587-593. https://doi.org/10.1890/04-1069

Koltz, A. M., Burkle, L. A., Pressler, Y., Dell, J. E., Vidal, M. C., Richards, L. A., \& Murphy, S. M. (2018). Global change and the importance of fire for the ecology and evolution of insects. Current Opinion in Insect Science, 29, 110-116. https://doi.org/10.1016/j.cois.2018.07.015

Kowaljow, E., Morales, M. S., Whitworth-Hulse, J. I., Zeballos, S. R., Giorgis, M. A., Rodríguez Catón, M., \& Gurvich, D. E. (2018). A 55year-old natural experiment gives evidence of the effects of changes in fire frequency on ecosystem properties in a seasonal Subtropical Dry forest. Land Degradation and Development, 30, 266277.

Kral, K. C., Limb, R. F., Harmon, J. P., \& Hovick, T. J. (2017). Arthropods and fire: Previous research shaping future conservation. Rangeland Ecology and Management, 70(5), 589-598. https://doi.org/10.1016/j. rama.2017.03.006

Lamont, B. B., \& Downes, K. S. (2011). Fire-stimulated flowering among resprouters and geophytes in Australia and South Africa. Plant Ecology, 212(12), 2111-2125. https://doi.org/10.1007/s11258-011-9987-y

Lazarina, M., Devalez, J., Neokosmidis, L., Sgardelis, S. P., Kallimanis, A. S., Tscheulin, T., ... Petanidou, T. (2019). Moderate fire severity is best for the diversity of most of the pollinator guilds in Mediterranean pine forests. Ecology, 100, e02615. https://doi.org/10.1002/ecy.2615

Lazarina, M., Sgardelis, S. P., Tscheulin, T., Devalez, J., Mizerakis, V., Kallimanis, A. S., ... Petanidou, T. (2017). The effect of fire history in shaping diversity patterns of flower-visiting insects in post-fire Mediterranean pine forests. Biodiversity and Conservation, 26(1), 115-131. https://doi.org/10.1007/s10531-016-1228-1

LoPresti, E. F., Van Wyk, J. I., Mola, J. M., Toll, K., Miller, T. J., \& Williams, N. M. (2018). Effects of wildfire on floral display size and pollinator community reduce outcrossing rate in a plant with a mixed mating system. American Journal of Botany, 105(7), 1154-1164. https://doi. org/10.1002/ajb2.1129

McKechnie, I. M., \& Sargent, R. D. (2013). Do plant traits influence a species' response to habitat disturbance? A meta-analysis. Biological Conservation, 168, 69-77. https://doi.org/10.1016/j. biocon.2013.09.023

Mola, J. M., \& Williams, N. M. (2018). Fire-induced change in floral abundance, density, and phenology benefits bumble bee foragers. Ecosphere, 9(1), e02056. https://doi.org/10.1002/ecs2.2056

Moretti, M., De Bello, F., Roberts, S. P., \& Potts, S. G. (2009). Taxonomical vs. functional responses of bee communities to fire in two contrasting climatic regions. Journal of Animal Ecology, 78(1), 98-108.

Moretti, M., Obrist, M. K., \& Duelli, P. (2004). Arthropod biodiversity after forest fires: Winners and losers in the winter fire regime of the southern Alps. Ecography, 27(2), 173-186. https://doi. org $/ 10.1111 / \mathrm{j} .0906-7590.2004 .03660 . x$ 
Ne'eman, G., \& Dafni, A. (1999). Fire, bees, and seed production in a Mediterranean key species Salvia fruticosa Miller (Lamiaceae). Israel Journal of Plant Sciences, 47(3), 157-163. https://doi. org/10.1080/07929978.1999.10676768

Ne'eman, G., Dafni, A., \& Potts, S. G. (2000). The effect of fire on flower visitation rate and fruit set in four core-species in east Mediterranean scrubland. Plant Ecology, 146(1), 97-104.

New, T. R. (2014). Insects, fire and conservation. Cham, Switzerland: Springer.

Ollerton, J., Winfree, R., \& Tarrant, S. (2011). How many flowering plants are pollinated by animals? Oikos, 120(3), 321-326. https://doi. org/10.1111/j.1600-0706.2010.18644.x

Olson, D. M., Dinerstein, E., Wikramanayake, E. D., Burgess, N. D., Powell, G. V. N., Underwood, E. C., ... Kassem, K. R. (2001). Terrestrial ecoregions of the World: A new map of life on Earth. BioScience, 51(11), 933938. https://doi.org/10.1641/0006-3568(2001)051[0933:TEOTW A]2.0.CO;2

Pausas, J. G. (2019). Generalized fire response strategies in plants and animals. Oikos, 128, 147-153.

Pausas, J. G., Belliure, J., Mínguez, E., \& Montagut, S. (2018). Fire benefits flower beetles in a mediterranean ecosystem. PLOS ONE, 13(6), e0198951. https://doi.org/10.1371/journal.pone.0198951

Pausas, J. G., \& Keeley, J. E. (2009). A burning story: The role of fire in the history of life. BioScience, 59, 593-601. https://doi.org/10.1525/ bio.2009.59.7.10

Pausas, J. G., \& Keeley, J. E. (2014). Evolutionary ecology of resprouting and seeding in fire-prone ecosystems. New Phytologist, 204, 55-65. https://doi.org/10.1111/nph.12921

Pausas, J. G. , \& Parr, C. L. (2018). Towards an understanding of the evolutionary role of fire in animals. Evolutionary Ecology, 32(2-3), 113-125. https://doi.org/10.1007/s10682-018-9927-6

Pausas, J. G., \& Ribeiro, E. (2017). Fire and plant diversity at the global scale. Global Ecology and Biogeography, 26, 889-897. https://doi. org/10.1111/geb.12596

Pellegrini, A. F. A., Ahlström, A., Hobbie, S. E., Reich, P. B., Nieradzik, L. P., Staver, A. C., ... Jackson, R. B. (2018). Fire frequency drives decadal changes in soil carbon and nitrogen and ecosystem productivity. Nature, 553, 194-198. https://doi.org/10.1038/nature24668

Peralta, G., Stevani, E. L., Chacoff, N. P., Dorado, J., \& Vázquez, D. P. (2017). Fire influences the structure of plant-bee net- works. Journal of Animal Ecology, 86(6), 1372-1379. https://doi. org/10.1111/1365-2656.12731

Pilon, N. A., Hoffmann, W. A., Abreu, R. C., \& Durigan, G. (2018). Quantifying the short-term flowering after fire in some plant communities of a cerrado grassland. Plant Ecology and Diversity, 11(3), 259-266. https://doi.org/10.1080/17550874.2018.1517396

Ponisio, L. C., Wilkin, K., M'Gonigle, L. K., Kulhanek, K., Cook, L., Thorp, R., ... Kremen, C. (2016). Pyrodiversity begets plant-pollinator community diversity. Global Change Biology, 22, 1794-1808. https://doi. org/10.1111/gcb.13236

Potts, S. G., Biesmeijer, J. C., Kremen, C., Neumann, P., Schweiger, O., \& Kunin, W. E. (2010). Global pollinator declines: Trends, impacts and drivers. Trends in Ecology and Evolution, 25(6), 345-353. https://doi. org/10.1016/j.tree.2010.01.007

Potts, S. G., Vulliamy, B., Dafni, A., Ne'eman, G., O'Toole, C., Roberts, S., \& Willmer, P. (2003). Response of plant-pollinator communities to fire: Changes in diversity, abundance and floral reward structure. Oikos, 101(1), 103-112. https://doi. org/10.1034/j.1600-0706.2003.12186.X

Pressler, Y., Moore, J. C., \& Cotrufo, M. F. (2019). Belowground community responses to fire: Meta-analysis reveals contrasting responses of soil microorganisms and mesofauna. Oikos, 128, 309-327.
R Core Team. (2018). R: A language and environment for statistical computing. Vienna, Austria: R Foundation for Statistical Computing. Retrieved from https: //www.R-project.org/

Rosenberg, M. S., Rothstein, H. R., \& Gurevitch, J. (2013). Effect sizes: Conventional choices and calculations. In J. Koricheva, J. Gurevitch, \& K. Mengersen (Eds.), Handbook of meta-analysis in ecology and evolution (pp. 61-71). NJ: Princeton University Press.

Stevens, J. R., \& Taylor, A. M. (2009). Hierarchical dependence in metaanalysis. Journal of Educational and Behavioral Statistics, 34(1), 46-73. https://doi.org/10.3102/1076998607309080

Swengel, A. B. (1998). Effects of management on butterfly abundance in tallgrass prairie and pine barrens. Biological Conservation, 83(1), 77-89. https://doi.org/10.1016/S0006-3207(96)00129-2

Swengel, A. B. (2001). A literature review of insect responses to fire, compared to other conservation managements of open habitat. Biodiversity and Conservation, 10(7), 1141-1169.

Swengel, A. B., \& Swengel, S. R. (2007). Benefit of permanent non-fire refugia for Lepidoptera conservation in fire-managed sites. Journal of Insect Conservation, 11(3), 263-279. https://doi.org/10.1007/ s10841-006-9042-9

Swengel, A. B., \& Swengel, S. R. (2013). Decline of Hesperia ottoe (Lepidoptera: Hesperiidae) in northern tallgrass prairie pre- serves. Insects, 4(4), 663-682. https://doi.org/10.3390/insec ts 4040663

Taylor, A. N., \& Catling, P. M. (2011). Bees and butterflies in burned and unburned alvar woodland: Evidence for the importance of postfire succession to insect pollinator diversity in an imperiled ecosystem. The Canadian Field-Naturalist, 125(4), 297-306. https://doi. org/10.22621/cfn.v125i4.1258

Thom, M. D., Daniels, J. C., Kobziar, L. N., \& Colburn, J. R. (2015). Can butterflies evade fire? Pupa location and heat tolerance in fire prone habitats of Florida. PLOS ONE, 10(5), e0126755. https://doi. org/10.1371/journal.pone.0126755

Van Nuland, M. E., Haag, E. N., Bryant, J. A. M., Read, Q. D., Klein, R. N., Douglas, M. J., ... Bailey, J. K. (2013). Fire promotes pollinator visitation: Implications for ameliorating declines of pollination services. PLOS ONE, 8(11), e79853. https://doi.org/10.1371/journ al.pone. 0079853

Viechtbauer, W. (2010). Conducting meta-analyses in R with the metafor package. Journal of Statistical Software, 36(3), 1-48.

Vieira, M. C., Cianciaruso, M. V., \& Almeida-Neto, M. (2013). Plant-pollinator coextinctions and the loss of plant functional and phylogenetic diversity. PLOS ONE, 8(11), e81242.

Wikars, L. O. (1997). Effects of forest fire and the ecology of fire-adapted insects. Uppsala, Sweden: Acta Universitatis Upsaliensis.

Wilcock, C., \& Neiland, R. (2002). Pollination failure in plants: Why it happens and when it matters. Trends in Plant Science, 7(6), 270-277. https ://doi.org/10.1016/S1360-1385(02)02258-6

Williams, N. M., Crone, E. E., T'ai, H. R., Minckley, R. L., Packer, L., \& Potts, S. G. (2010). Ecological and life-history traits predict bee species responses to environmental disturbances. Biological Conservation, 143(10), 2280-2291. https://doi.org/10.1016/j. biocon.2010.03.024

Winfree, R., Aguilar, R., Vázquez, D. P., LeBuhn, G., \& Aizen, M. A. (2009). A meta-analysis of bees' responses to anthropogenic dis- turbance. Ecology, 90(8), 2068-2076. https://doi.org/10.1890/081245.1

Zedler, P. H. (1995). Fire frequency in southern California shrublands: Biological effects and management options. In J. E. Keeley \& T. Scott (Eds.), Brushfires in California: Ecology and management (pp. 101-112). Fairfield, WA: International Association of Wildland Fire. 


\section{BIOSKETCH}

We all share an interest on how disturbances affect biodiversity, including studies on the response of several organizing levels (landscapes, communities, populations, species) to fire regime and habitat fragmentation. Specific interests of each author can be found on their web pages: L. M. Carbone (https://www.resea rchgate.net/profile/Lucas_Carbone2), J. Tavella (https://www. researchgate.net/profile/Julia_Tavella), R. Aguilar (https://www. researchgate.net/profile/Ramiro_Aguilar), J. G. Pausas (https:// www.uv.es/jgpausas/).

\section{SUPPORTING INFORMATION}

Additional supporting information may be found online in the Supporting Information section at the end of the article.

\section{APPENDIX : DATA SOURCES}

\section{Literature included in the meta-analysis}

Araújo, R. A., Araújo, M. S., Gonring, A. H., \& Guedes, R. N. (2005). Impact of controlled sugarcane straw burning on local insect community. Neotropical Entomology, 34(4), 649-658.

Benson, T. J., Dinsmore, J. J., \& Hohman, W. L. (2007). Responses of plants and arthropods to burning and disking of riparian habitats. The Journal of Wildlife Management, 71(6), 1949-1957.

Bogusch, P., Blažej, L., Trýzna, M., \& Heneberg, P. (2015). Forgotten role of fires in Central European forests: Critical importance of early postfire successional stages for bees and wasps (Hymenoptera: Aculeata). European Journal of Forest Research, 134(1), 153-166.

Brown, J., \& York, A. (2017). Fly and wasp diversity responds to elements of both the visible and invisible fire mosaic. International Journal of Wildland Fire, 26(5), 434-443.

Campbell, J. W., Hanula, J. L., \& Waldrop, T. A. (2007). Effects of prescribed fire and fire surrogates on floral visiting insects of the blue ridge province in North Carolina. Biological Conservation, 134(3), 393-404.

Carbone, L. M., \& Aguilar, R. (2017). Fire frequency effects on soil and pollinators: What shapes sexual plant reproduction? Plant Ecology, 218(11-12), 1283-1297.

Cleary, D. F., \& Mooers, A. Ø. (2004). Butterfly species richness and community composition in forests affected by ENSO-induced burning and habitat isolation in Borneo. Journal of Tropical Ecology, 20(4), 359-367.

Cleary, D. F., Mooers, A. Ø., Eichhorn, K. A., Van Tol, J., De Jong, R., \& Menken, S. B. (2004). Diversity and community composition of butterflies and odonates in an ENSO-induced fire affected habitat mosaic: A case study from East Kalimantan, Indonesia. Oikos, 105(2), 426-448.

Da Silva Giehl, N. F., Valadão, M. B. X., Brasil, L. S., dos Santos, J. O., Almeida, S. M., Lenza, E., \& dos Anjos-Silva, E. J. (2013). O Efeito do fogo sobre a comunidade de abelhas Euglossini (Hymenoptera:
Apidae) em floresta de transição Cerrado-Amazônia (Mato Grosso, Brasil). EntomoBrasilis, 6(3), 178-183.

Doxon, E. D., Davis, C. A., Fuhlendorf, S. D., \& Winter, S. L. (2011). Aboveground macroinvertebrate diversity and abundance in sand sagebrush prairie managed with the use of pyric herbivory. Rangeland Ecology \& Management, 64(4), 394-403.

Elia, M., Lafortezza, R., Tarasco, E., Colangelo, G., \& Sanesi, G. (2012). The spatial and temporal effects of fire on insect abundance in Mediterranean forest ecosystems. Forest Ecology and Management, 263, 262-267.

Fleishman, E. (2000). Monitoring the response of butterfly communities to prescribed fire. Environmental Management, 26(6), 685-695.

Fraser, M. W. (1989). Short-term responses of birds to fire in old mountain fynbos. Ostrich: Journal of African Ornithology, 60(4), 172-182.

Geerts, S., Malherbe, S. D., \& Pauw, A. (2012). Reduced flower visitation by nectar-feeding birds in response to fire in Cape fynbos vegetation, South Africa. Journal of Ornithology, 153(2), 297-301.

Hiers, J. K., Wyatt, R., \& Mitchell, R. J. (2000). The effects of fire regime on legume reproduction in longleaf pine savannas: Is a season selective? Oecologia, 125(4), 521-530.

Kambach, S., Guerra, F., Beck, S. G., Hensen, I., \& Schleuning, M. (2013). Human-induced disturbance alters pollinator communities in tropical mountain forests. Diversity, 5(1), 1-14.

Kaynaș, B. Y., \& Gürkan, B. (2007). Species diversity of butterflies in Turkish Pinus brutia forest ecosystems after fire. Entomological News, 118(1), 31-39.

Kunte, K. J. (1997). Seasonal patterns in butterfly abundance and species diversity in four tropical habitats in northern Western Ghats. Journal of Biosciences, 22(5), 593-603.

Lazarina, M., Sgardelis, S. P., Tscheulin, T., Devalez, J., Mizerakis, V., Kallimanis, A. S., \& Petanidou, T. (2017). The effect of fire history in shaping diversity patterns of flower-visiting insects in post-fire Mediterranean pine forests. Biodiversity and Conservation, 26(1), 115131.

Leuenberger, W., Bearer, S., Duchamp, J., Johnson, S., Leppo, B., McElhenny, P., \& Larkin, J. (2016). A comparison of Lepidoptera communities inhabiting restored and late successional pitch pine- scrub oak barrens in Pennsylvania. Natural Areas Journal, 36, 38-47. Lillie, S.

(2011). The role of fire in shaping pollinator communities: a post burn analysis of bees in serpentine habitat. Doctoral dissertation, Humboldt State University.

Lomond, D., \& Larson, D. J. (1983). Honey bees, Apis mellifera (Hymenoptera: Apidae), as pollinators of lowbush blueberry, Vaccinium angustifolium, on Newfoundland coastal barrens. The Canadian Entomologist, 115(12), 1647-1651.

Love, B. G., \& Cane, J. H. (2016). Limited direct effects of a massive wildfire on its sagebrush steppe bee community. Ecological Entomology, 41(3), 317-326.

Mateos, E., Santos, X., \& Pujade-Villar, J. (2011). Taxonomic and functional responses to fire and post-fire management of a Mediterranean Hymenoptera community. Environmental Management, 48(5), 10001012.

Mclver, J., \& Macke, E. (2014). Short-term butterfly response to sagebrush steppe restoration treatments. Rangeland Ecology \& Management, 67(5), 539-552.

Mestre, L. A., Cochrane, M. A., \& Barlow, J. (2013). Long-term changes in bird communities after wildfires in the central Brazilian Amazon. Biotropica, 45(4), 480-488.

Milberg, P., Bergman, K. O., Norman, H., Pettersson, R. B., Westerberg, L., Wikars, L. O., \& Jansson, N. (2015). A burning desire for smoke? Sampling insects favoured by forest fire in the absence of fire. Journal of Insect Conservation, 19(1), 55-65.

Mola, J. M., \& Williams, N. M. (2018). Fire-induced change in floral abundance, density, and phenology benefits bumble bee foragers. Ecosphere, 9(1), e02056. 
Moretti, M., Obrist, M. K., \& Duelli, P. (2004). Arthropod biodiversity after forest fires: winners and losers in the winter fire regime of the southern Alps. Ecography, 27(2), 173-186.

Moretti, M., Duelli, P., \& Obrist, M. K. (2006). Biodiversity and resilience of arthropod communities after fire disturbance in temperate forests. Oecologia, 149(2), 312-327.

Nagel, H. G. (1973). Effect of spring prairie burning on herbivorous and non-herbivorous arthropod populations. Journal of the Kansas Entomological Society, 46(4), 485-496.

Ne'eman, G., \& Dafni, A. (1999). Fire, bees, and seed production in a Mediterranean key species Salvia fruticosa Miller (Lamiaceae). Israel Journal of Plant Sciences, 47(3), 157-163.

Ne'eman, G., Dafni, A., \& Potts, S. G. (2000). The effect of fire on flower visitation rate and fruit set in four core-species in east Mediterranean scrubland. Plant Ecology, 146(1), 97-104.

Neumann, F. G., \& Tolhurst, K. (1991). Effects of fuel reduction burning on epigeal arthropods and earthworms in dry sclerophyll eucalypt forest of west-central Victoria. Australian Journal of Ecology, 16(3), 315-330.

Newton, J. L., Kazmaier, R. T., \& Sissom, W. D. (2016). Effects of varying fire-return interval on terrestrial macro-arthropods in a mesquiteencroached shortgrass prairie: Abundance, diversity, and biomass. Southwestern Entomologist, 41(4), 945-962.

Nyoka, S. (2010). Effects of fuel-reduction treatments on pollinators in a Pinyon-Juniper woodland (Arizona). Ecological Restoration, 28(2), 119-121.

Peralta, G., Stevani, E. L., Chacoff, N. P., Dorado, J., \& Vázquez, D. P. (2017). Fire influences the structure of plant-bee networks. Journal of Animal Ecology, 86(6), 1372-1379.

Potts, S. G., Dafni, A., \& Ne'eman, G. (2001a). Pollination of a core flowering shrub species in Mediterranean phrygana: Variation in pollinator diversity, abundance and effectiveness in response to fire. Oikos, 92(1), 71-80.

Potts, S. G., Petanidou, T., Roberts, S., O'Toole, C., Hulbert, A., \& Willmer, P. (2006). Plant-pollinator biodiversity and pollination services in a complex Mediterranean landscape. Biological Conservation, 129(4), 519-529.

Potts, S. G., Willmer, P., Dafni, A., \& Ne'eman, G. (2001b). The utility of fundamental ecological research of plant-pollinator interactions as the basis for landscape management practices. In: VIII International Symposium on Pollination-Pollination: Integrator of Crops and Native Plant Systems, 561, pp. 141-144.

Potts, S. G., Vulliamy, B., Dafni, A., Ne'eman, G., \& Willmer, P. (2003a). Linking bees and flowers: How do floral communities structure pollinator communities? Ecology, 84(10), 2628-2642.

Potts, S. G., Vulliamy, B., Dafni, A., Ne'eman, G., O'toole, C., Roberts, S., \& Willmer, P. (2003b). Response of plant-pollinator communities to fire: Changes in diversity, abundance and floral reward structure. Oikos, 101(1), 103-112.

Potts, S. G., Vulliamy, B., Roberts, S., O'Toole, C., Dafni, A., Ne'eman, G., \& Willmer, P. (2005). Role of nesting resources in organising diverse bee communities in a Mediterranean landscape. Ecological Entomology, 30(1), 78-85.

Powell, A. F., Busby, W. H., \& Kindscher, K. (2007). Status of the regal fritillary (Speyeria idalia) and effects of fire management on its abundance in northeastern Kansas, USA. Journal of Insect Conservation, 11(3), 299-308.

Pryke, J. S., \& Samways, M. J. (2012). Differential resilience of invertebrates to fire. Austral Ecology, 37(4), 460-469.

Rhodes, E. C., Bates, J. D., Sharp, R. N., \& Davies, K. W. (2010). Fire effects on cover and dietary resources of sage-grouse habitat. The Journal of Wildlife Management, 74(4), 755-764.
Rodríguez, A., \& Kouki, J. (2015). Emulating natural disturbance in forest management enhances pollination services for dominant Vaccinium shrubs in boreal pine-dominated forests. Forest Ecology and Management, 350, 1-12.

Rodríguez, A., \& Kouki, J. (2016). Disturbance-mediated heterogeneity drives pollinator diversity in boreal managed forest ecosystems. Ecological Applications, 27(2), 589-602.

Rubene, D., Schroeder, M., \& Ranius, T. (2015). Diversity patterns of wild bees and wasps in managed boreal forests: Effects of spatial structure, local habitat and surrounding landscape. Biological Conservation, 184, 201-208.

Rudolph, D. C., \& Ely, C. A. (2000). The influence of fire on lepidopteran abundance and community structure in forested habitats of eastern Texas. Texas Journal of Science, 52(4), 127-138.

Salvato, M. H., \& Salvato, H. L. (2010). Notes on the status and ecology of Strymon acis bartrami (Lycaenidae) in Everglades National Park. The Journal of the Lepidopterists' Society, 64(3), 154-160.

Sasal, Y., Farji-Brener, A. , \& Raffaele, E. (2017). Firemodulates the effects of introduced ungulates on plant-insect interactions in a Patagonian temperate forest. Biological Invasions, 19(8), 2459-2475.

Scandurra, A., Magliozzi, L., Aria, M., \& D'Aniello, B. (2014). Short-term effects of fire on Papilionoidea (Lepidoptera) communities: A pilot study in Mediterranean maquis shrubland. Italian Journal of Zoology, 81(4), 599-609.

Semmler, S. J. (2015). Community composition and pollination network structure in a fire managed Canadian tall grass prairie. MS Thesis. University of Manitoba.

Stow, A., Silberbauer, L., Beattie, A. J., \& Briscoe, D. A. (2007). Fine-scale genetic structure and fire-created habitat patchiness in the Australian allodapine bee, Exoneura nigrescens (Hymenoptera: Apidae). Journal of Heredity, 98(1), 60-66.

Swengel, A. B. (1998). Effects of management on butterfly abundance in tallgrass prairie and pine barrens. Biological Conservation, 83(1), 77-89.

Swengel, A. B., \& Swengel, S. R. (2007). Benefit of permanent non-fire refugia for Lepidoptera conservation in fire-managed sites. Journal of Insect Conservation, 11(3), 263-279.

Taylor, A. N., \& Catling, P. M. (2011). Bees and butterflies in burned and unburned alvar woodland: Evidence for the importance of postfire succession to insect pollinator diversity in an imperiled ecosystem. The Canadian Field-Naturalist, 125(4), 297-306.

Tornyie, F., \& Kwapong, P. K. (2015). Nesting ecology of stingless bees and potential threats to their survival within selected landscapes in the northern Volta region of Ghana. African Journal of Ecology, 53(4), 398-405.

Tulloch, A. I., \& Dickman, C. R. (2007). Effects of food and fire on the demography of a nectar-feeding marsupial: A field experiment. Journal of Zoology, 273(4), 382-388.

Van Nuland, M. E., Haag, E. N., Bryant, J. A., Read, Q. D., Klein, R. N., Douglas, M., G. K. Bailey (2013). Fire promotes pollinator visitation: Implications for ameliorating declines of pollination services. PLoS ONE, 8(11), e79853.

Vigueira, P. A., Campbell, J., Vigueira C., \& Greenberg K. (2016). Effects of continued prescribed fire and fire surrogates on insect pollinators of the blue ridge province in North Carolina. Congress conference: 2016 International Congress of Entomology. USA.

Vinson, S. B., \& Frankie, G. W. (1991). Nest variability in Centris aethyctera (Hymenoptera: Anthophoridae) in response to nesting site conditions. Journal of the Kansas Entomological Society, 64(2), 156-162.

Welti, E. A., \& Joern, A. (2018). Fire and grazing modulate the structure and resistance of plant-floral visitor networks in a tallgrass prairie. Oecologia, 186(2), 517-528. 